Research Article

\title{
The Use of Dynamic Geometry Software from a Pedagogical Perspective: Current Status and Future Prospects
}

\author{
Emin İBİL̇ *1 (1D) \\ ${ }^{1}$ Afyonkarahisar Health Sciences University, Faculty of Health Sciences, Afyonkarahisar, Turkey, eminibili@gmail.com \\ * Corresponding Author: eminibili@gmail.com
}

\begin{tabular}{|c|c|}
\hline Article Info & Abstract \\
\hline & $\begin{array}{l}\text { This research firstly aims to reveal the pedagogical potentials and } \\
\text { limitations of dynamic geometry software (DGS). For this purpose, } \\
\text { research on Cabri (2D/3D/Plus), the Geometer's Sketchpad, }\end{array}$ \\
\hline Received: 18 June 2019 & GoogleSketchUp, GeoGebra and Logo software was reviewed and \\
\hline Accepted: 20 September 2019 & $\begin{array}{l}\text { compiled. As a result of the research, it appears that DGS offers an } \\
\text { effective pedagogical environment because of its ability to interact with }\end{array}$ \\
\hline Keywords: & $\begin{array}{l}\text { digital materials and allow for geometric objects to be seen from all } \\
\text { sides. However, we found that teachers have some problems in }\end{array}$ \\
\hline $\begin{array}{l}\text { software, pedagogy, mathematics } \\
\text { teacher }\end{array}$ & $\begin{array}{l}\text { combining DGS with class pedagogy. In this study, the effects of } \\
\text { gender, age, education level, skill in using technology and the influence } \\
\text { of professional experience were also examined in relation to primary }\end{array}$ \\
\hline DOI: $10.18009 /$ jcer.579517 & $\begin{array}{l}\text { school mathematics teachers preferences in using DGS. As a result of } \\
\text { this research, it was found that GeoGebra and Cabri were the most- }\end{array}$ \\
\hline Publication Language: English & $\begin{array}{l}\text { used DGS packages by primary school mathematics teachers, while } \\
\text { other geometry software was less preferred by teachers. }\end{array}$ \\
\hline
\end{tabular}

open access CrossMark (C)

To cite this article: İbili, E. (2019). The use of dynamic geometry software from a pedagogical perspective: current status and future prospects. Journal of Computer and Education Research, 7 (14), 337-355. DOI: $10.18009 /$ jcer.579517

\section{Introduction}

When technology and computers are used effectively, they are seen as powerful tools, which facilitate appropriate modelling, research, reasoning, exploration and understanding regarding knowledge for teaching geometry (Wiest, 2001). The issue of how technology is becoming more involved in education, as well as how to make effective use of educationtechnology cooperation, has started to be considered more. The most common teaching method in geometry has always been to convey information to students, but PISA (Programme for International Student Assessment) and similar examinations indicate that this method is no longer sufficient. PISA regularly assesses mathematics, science literacy and reading skills in the context of OECD member countries and other participating countries every three years. It aims to measure the ability of students to relate and solve problems 
from real life and improve, through observation, the shortcomings in their respective country (Taş, Arıcı, Ozarkan \& Özgürlük, 2016). In recent years, these external factors have also been turned into new constructivist education models. Holloway (1999) emphasized that the constructivist model is not intended to provide students with skills to solve problems from real life. In this training model, the achievements of high-level learning skills and student needs are important. The researcher emphasized the fact that many individuals had learned how to learn before being taught via the constructivist model (Holloway, 1999). Therefore, for present-day geometry, it can be assumed that technology and the constructivist approach model are predictors of each other. However, for geometry, it is still under investigation which model is the best for technological education and training. İçel (2011) emphasized that dynamic geometry software (DGS) has especially begun to become more involved with the teaching of geometry.

Nowadays, considering the possibilities provided by technology and examinations that investigate the success of education, it is necessary to apply a more active approach instead of delivering lectures on geometry, which rely on memorization, are teacher-centred and have limitations (Bray \& Tangney, 2017). Geometry teaching should be able to provide a representative sample of what the student will encounter in real life, encouraging them to think with the use of technology. An important component of this goal is pedagogy. Once pedagogy is revised and regulated to complement the transition from traditional teaching to technology-assisted teaching, exploring geometry with the help of technology should help to achieve the desired goal (Pavlovičová \& Švecová, 2015, Çetin \& Mirasyedioğlu, 2019).

Pedagogy, which is derived from paediatrics, which means child in ancient Greek, and agogus, which means leadership, is defined as the art and science of teaching children (Ozuah, 2016). In general, the pedagogy is a systematic guide that includes specific principles and techniques that instructors must follow to achieve good learning outcomes and to demonstrate good teaching skills (Balram, 2019). Pedagogical knowledge is a teaching tool, which transforms information about a topic into the most understandable form for the student (Saeli, Perrent \& Zwaneveld, 2011).

According to Leung (2011), a qualified pedagogical environment should encourage the learner to take action, but also give them the opportunity to make meaning. The dynamic geometry environment is also targeted in order to provide a facilitative and empowering 
pedagogical environment for students and teachers in which to conduct empirical research on geometric objects (Leung, 2011). According to Gooler, Kantzer and Knuth (2000), the most important way to incorporate technology into classroom pedagogy is through the ability of teachers to integrate curriculum teaching and technology in an easy and trouble-free way. Mishra and Koehler (2009) points out that teachers are not able to combine technology with classroom pedagogy because they do not have enough experience to use technology to support teaching and learning. According to these researchers, the training programmes devised for teachers are insufficient in terms of the use of the technology, which means that the teachers do not see themselves as adequately prepared, let alone eager to use technology in the classroom. In addition, technological tools are associated with time-consuming activities, which must be squeezed into an intensive curriculum (Mishra \& Koehler, 2009).

As Wiest (2001) points out, technology alone is not functional, and the effective use of technology in geometry depends on the teaching method. Mishra and Koehler (2006) developed a model of technological pedagogical content knowledge by combining technological tools, pedagogy and knowledge to be learned. Koehler, Mishra and Yahya (2007) showed that the components of this model are involved in dynamic interaction, which emphasizes the need for the constantly active maintenance and renewal of the dynamics between these components for successful teaching using technology. This is because it is always necessary to examine technology and its tools in order to develop pedagogical techniques. These techniques make it easy to understand the concepts and representations of the codes in technology, to construct and use content, and to develop solutions in the face of the difficulties in understanding the concepts (Koehler et al., 2007). For Jones (2002), DGS refers to systems that provide tools with which to create geometric objects by using basic drawing elements such as point, line, etc.

Dynamic software in geometry teaching is used because it offers more interaction possibilities and facilitates learning by allowing for geometric objects to be visible from all sides (Çelik, Erduran \& Eryiğit, 2016). According to Guven and Karatas (2003), software liberates geometric shapes from the static conditions on paper, allowing them to be used in a dynamic and variable manner in the computer environment. Thus, it provides the opportunity to create ideas, comparisons, generalizations, inferences and trial repetitions, as well as develop strategic solutions (Güven \& Karataş, 2003). Dixon (1997) hypothesizes that the teaching of geometry requires much more visualization than other taught subjects. 
However, almost all of these needs have been overlooked in secondary school education for many years. According to the researcher, this is because of the lack of effective and easily accessible teaching that can be achieved in schools. The software allows students to understand geometry problems, estimate their solutions, and develop associative skills, group work and interactivity (Jones, 2002). It is worth noting that DGS is a powerful tool for teaching geometry, as well as being a stand-alone tutorial aid (Wiest, 2001).

In the absence of a teacher, computer software alone does not have an event planning program to match the direction of learning and students' skill level. Therefore, in DGSassisted geometry teaching, teachers should always be a guide for their students (Jones, 2002; Wiest, 2001). The teacher should observe them during assigned tasks and problem-solving to ensure that every student benefits. In this way, the teacher can help the student to recognize whether their progress is at the expected rate. Students who are engaged in an activity and who cannot progress should aim to gain understanding and skills by being given a chance to practise more (Jones, 2002).

DGS can enhance geometry learning to a higher level with continuous motion (such as dragging), connectivity and communication features (Sinclair \& Crespo, 2006). The dragging feature allows shapes to be seen from different viewpoints, to examine shape features (edge, angle etc.), to recognize differences and similarities, and to show transformations of shapes (Sinclair \& Crespo, 2006). Students are familiar with fixed geometric shapes on paper, so they do not use dragging with the mouse much when using software for the first time. As students become accustomed to using the software, they realize that dragging is important (Arzarello, Olivero, Paola \& Robutti, 2002). As well as DGS provides a connection between visual-algebraic geometric representations and modes of thinking, it helps to provide a connection between real life and geometric representations (Gökkurt, Dündar, Soylu \& Tatar 2012). Students also become familiar with the common language of geometry as they use the communication features (mathematics language, commands) of the DGS (Sinclair \& Crespo, 2006). 


\section{Literature review}

This section reviews related work on dynamic geometry software from a pedagogical perspective. As can be seen in the findings section of this study, the most commonly used DGS softwares in the classroom by teachers were Cabri 2D/3D, GeoGebra, Sketchpad, Google SketchUp, and Logo. This finding was confirmed by different researchers (Günhan \& Açan, 2016; Hohenwarter \& Jones, 2007). Therefore, in the scope of this research, only these five DGS software were examined from a pedagogical perspective.

\section{Cabri 3D}

With Cabri 3D, 2D and Plus, complex constructions can be made separately and transformed into each other, while shapes can be related to real-life forms and misunderstandings caused by school geometry books can be accurately resolved (Eryiğit, 2010). While Cabri 3D can successfully support the curriculum in the teaching of prisms, pyramids, volume and symmetry, in turn improving spatial skills, visualization skills and reasoning, and developing associative skills in the majority of students (Çelik, Erduran \& Eryiğit, 2016; Priatna, 2017 ). In some studies (Şimşek \& Yücekaya, 2014), the superiority of traditional methods in terms of spatial visualization skills was not found. Research has shown that, when a non-command point was dragged in activities on cones, spheres and cylinders involving Cabri 3D, complicated shapes were created, while non-command points could not be fixed (Uğur, Urhan \& Kocadere, 2016). Many students and teachers have mentioned that Cabri 3D supports geometry teaching in relation to motivating, engaging, providing unlimited experimental possibilities, being more instructive and memorable than traditional geometry lessons (Gökkurt, Deniz, Soylu \& Akgün, 2012; Köse, 2008; Şimşek \& Yücekaya, 2014; Uğur, Urhan \& Kocadere, 2016).

\section{Geometer's Sketchpad}

One of the important features of the Geometer's Sketchpad (GSP) is its effective visualization feature (Adulyasas \& Abdul Rahman, 2014). It has been reported, in some studies, that geometric thinking skills related to angles, polygons, 2D and 3D shapes, rotation and rotation skills, and visualization skills have improved by delivering GSPsupported geometry lessons (Adulyasas \& Abdul Rahman, 2014; Dixon, 1997; Tieng \& Eu, 2014). It has been noted that one particular study found that cone nets could not be understood with the use of GSP, with teachers instead having to explain them again with 
concrete models and the paper-folding method (Adulyasas \& Abdul Rahman, 2014). Some studies have also reported that no significant increase was observed in terms of geometry achievement (Tieng \& Eu, 2014), while others confirmed an increase in Van Hiele levels, by delivering GSP-supported geometry teaching (Adulyasas \& Abdul Rahman, 2014). It has been reported that GSP-supported instruction motivates and prompts curiosity in students. In addition, in the classroom, it is necessary to provide teacher guidance, as well as promote interactive activities and brainstorming ideas, thus giving students the opportunity to test out their abilities, while increasing their capacity for success and effective working in relation to their skills (Adulyasas \& Abdul Rahman, 2014; Tieng \& Eu, 2014).

Google Sketchup

Although Google SketchUp is widely used in architectural and engineering areas, it can be used as DGS because it is easily accessible and free, provides an active geometry learning environment and can be learned in a short time (Chou, Chen, Wu \& Carey, 2017). According to the research, Google SketchUp can contribute as much as solid materials to mental rotation skills, as well as increase the understanding of prismatic issues and volume calculation in the curriculum (Khine, 2017). Among the disadvantages of the software are that it is not possible to obtain $3 \mathrm{D}$ shapes by pressing a single button; rather, generating the desired 3D shape, by converting a 2D shape to a 3D shape, or a 3D shape to another 3D shape, only slows down the functionality. However, it is believed that this can make a positive contribution if the student also thinks that they have seen connections between the 2D and 3D forms through this transition. It has been emphasized that students sometimes have difficulty in turning downwards and drawing a straight line on a figure, which is parallel to the axis (Kurtuluş \& Uygan, 2016). However, the possibility of regional colouring for calculations, such as for volume, or questions about prisms, allows students to better understand the shapes of the parts asked for in the prism sections, which in turn makes the calculations easier (Kurtuluş \& Uygan, 2016). According to candidate teachers, as reported in Kurtuluş \& Uygan's (2016) research, the use of software takes time, sometimes slows down and can be difficult primary school students to understand. However, for Erkoç, Gecü \& Erkoç (2013), this kind of software can be learned quickly and easily. 
GeoGebra

GeoGebra's ability to create dynamic visualization and algebraic operations on a single screen is said to be the most important feature distinguishing this from other software (Hohenwarter, Hohenwarter \& Lavicza, 2008; Pereira, Jardim \& da Silva, 2017). It strengthens the notion that the triangulation of students is effective in visualizing the selection of the GeoGebra technique in the drawing on paper (İçel, 2011; Çiftçi \& Tatar, 2014). GeoGebra has been noted in some studies as being influential in terms of motivating, entertaining, enhancing success, developing reasoning and visualization skills, visualizing and integrating algebraic activities (Pereira, Jardim \& da Silva, 2017). Research has also indicated that students are hesitant about the results they find when applying Pythagoras' solutions to software-based algebraic activities (Filiz, 2009). It has been observed that mathematical literacy progresses with GeoGebra-supported geometry. Symbolization from mathematical literacy sub-steps, using tools, modelling and problem-solving is more evident, although it has been emphasized that the development of reasoning, communication and discussion skills at lower levels is weak. It has been reported that the need for assistance is also increased in areas where information is necessary (Romeo, del Mar Garcia \& Codina, 2015). Teacher guidance in the development of reasoning, communication and discussion skills, the regularization of classroom discussions at the end of each lesson, the diversification of samples, and the awareness of students about achieving results in different ways are emphasized as important points (Filiz, 2009; İçel, 2011; Romeo, del Mar Garcia \& Codina, 2015). Also, Geogebra supported geometry teaching contributes to the development of students' geometric thinking levels (Kutluca, 2013).

$\log o$

Logo software is an object-oriented programming language developed by Papert and colleagues. Logo is a viable tool for naturally integrating geometry, reinforcing classroom interaction and computation ability (Valentine, 2018). Logo has been found to be more successful in teaching Euclidean and fractal geometry concepts (An \& Park, 2011). Also some researchers reported that geometric concepts such as line, plane, angle and polygons have been learned more effectively with Logo-assisted activities, teacher guidance and interclass interaction (An \& Park, 2011; Baki, \& Özpınar, 2007). Studies have also suggested that the use of the visual feedback function provided by Logo, as a trial-and-error method by 
students, should be limited. Because, the trial-and-error approach to reaching the goal can restrict the acquisition of analytical thinking skills in students (Baki, 2002; Simmons \& Cope, 1997).

Previous research has shown that DGS systems could be useful for teachers. However, previous research has been limited in examining the preferences frequency of DGS systems and some independent variables effects on this preferences. Also, there has been little research on DGS assisted geometry teaching on classroom pedagogy. For this reason, the purpose of this research is to examine the pedagogical potentials of some DGS softwares such as Cabri, GSP, Google SketchUp, GeoGebra and Logo. Also it is aimed that the exemine the effects of gender, grade, level of education, skill in using technology and professional experience on the preferences by primary mathematics teachers.

\section{Method}

This research has two purposes. Firstly, it aims to examine the literature on geometry teaching software and also the potential and limitations of geometry teaching using this software from pedagogical aspects. Another goal is to examine the effects of different variables in the preferences of DGS, when used as a teaching tool by teachers. For this purpose, research related to Cabri 2D/3D, GeoGebra, the GSP, Google SketchUp and Logo, when used in geometry teaching, has been examined and compiled. In addition, demographic data have been obtained online concerning 183 primary mathematics teachers in Turkey's schools, as well as information on the use of DGS by teachers in the last two years. The demographic data on primary mathematics teachers participating in the research are presented in Table 1.

Table 1. Demographic profile results

\begin{tabular}{llll}
\hline Demographic Profile (N = 183) & Category & Frequency & Percentage \% \\
\hline Gender & Male & 99 & 54.1 \\
& Female & 84 & 45.9 \\
Graduation Faculty & Education Faculty & 161 & 88 \\
& Science Faculty & 22 & 12 \\
Grade & Graduate & 166 & 90.7 \\
& Postgraduate & 17 & 9.3 \\
Experience (Year) & & & \\
\hline
\end{tabular}




\begin{tabular}{llll}
\hline & $<=10$ & 142 & 77.6 \\
Technology (IT) usage level & $>10$ & 41 & 22.4 \\
& & & \\
& Intermediate & 112 & 61.2 \\
& High & 71 & 38.8 \\
\hline
\end{tabular}

All analyses were performed with the SPSS 22.00 statistical package. Pearson's chisquared test with Yates's continuity correction and Fisher's exact tests were preferred for intergroup comparisons (Hinkle, Wiersma \& Jurs, 2003). When using the Fisher exact test, where chi-squared analysis cannot be performed (expected count $<5$ ), three teachers with low technology use are excluded. In addition, professional experience is divided into two categories: less than 10 years (less than one to five years and six to 10 years) and more than 10 years (11-16 years and more than 16 years).

\section{Findings}

The dynamic geometry softwares taken in this study and the usage frequency of these softwares by primary school mathematics teachers are given in Figure 1.

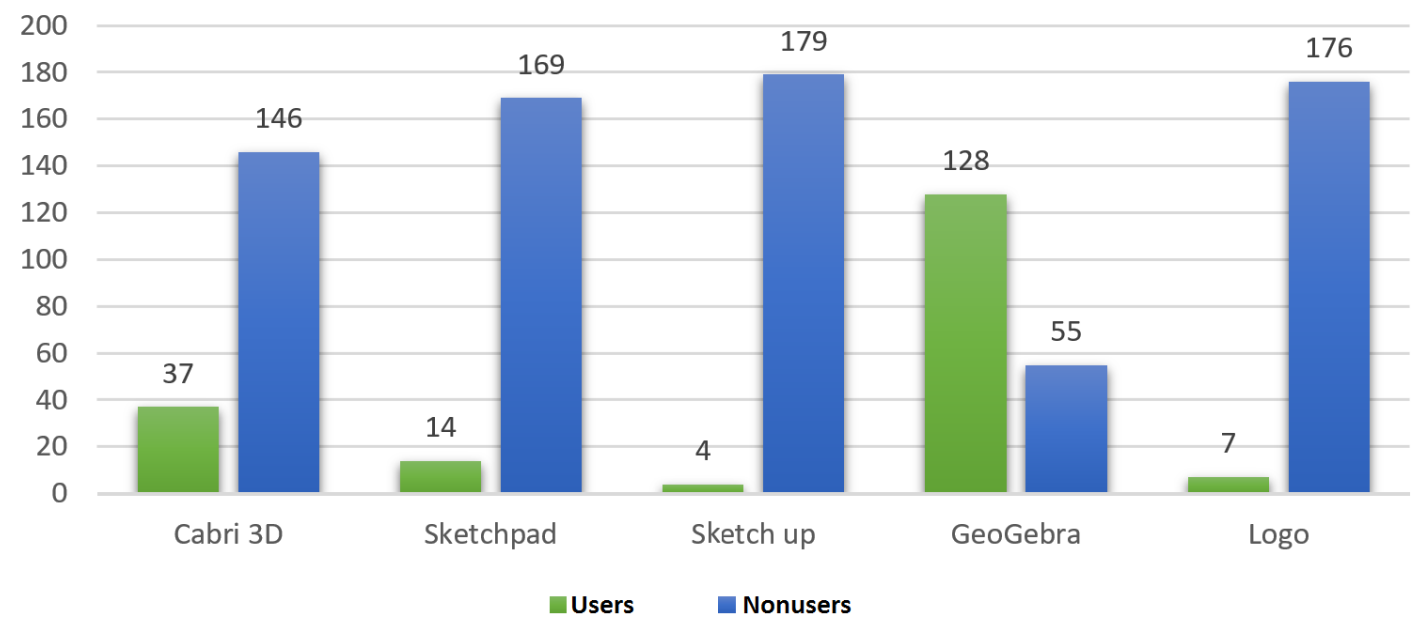

Figure 1. Usage frequency of DGS systems by primary mathematics teachers

As seen in Figure 1, Geogebra's use rate by primary mathematics teachers was found the highest (\%70). Cabri 3D is used by $20 \%$ of teachers, while Sketchpad, Logo, Scetchup are used by $7.7 \%, 3.8 \%$, \% 2 respectively of teachers. $25.1 \%$ of the teachers $(n=46)$ did not use any of the dynamic geometry softwares given in Fig 1 . In addition, $7.1 \%(n=13)$ of the teachers stated that they did not use other web-based and computer-based teaching materials while they use dynamic geometry software. The results of the chi-squared test to determine whether usage of teachers' DGS systems is dependent on gender are given in Table 2. 
Table 2. Distribution of DGS usage status by sex

\begin{tabular}{|c|c|c|c|c|c|c|}
\hline & \multicolumn{2}{|c|}{ Users } & \multicolumn{2}{|c|}{ Nonusers } & \multirow{2}{*}{$X^{2}$} & \multirow{2}{*}{$\mathrm{p}$} \\
\hline & Male & Female & Male & Female & & \\
\hline Cabri & 18 & 19 & 65 & 81 & .314 & $.575^{\mathrm{b}}$ \\
\hline Sketchpad & 7 & 7 & 92 & 77 & .002 & $.967^{b}$ \\
\hline Sketch up & 2 & 2 & 97 & 82 & & $1.00^{\mathrm{a}}$ \\
\hline GeoGebra & 68 & 60 & 31 & 24 & .162 & $.687^{b}$ \\
\hline Logo & 4 & 3 & 95 & 81 & & $1.00^{\mathrm{a}}$ \\
\hline
\end{tabular}

a Fisher's exact test (effectives $<5)$; ${ }^{\mathrm{b}}$ Pearson's Chi-squared test with Yates's continuity correction

According to Table 2, teachers' use of DGS is not dependent on gender variable (p> .05). Also, Table 3 shows the result of the chi-squared test to determine whether usage of teachers' DGS systems is dependent on their faculty which teachers have graduated.

Table 3. Distribution of DGS usage status by graduated faculty

\begin{tabular}{lcccccc}
\hline & \multicolumn{2}{c}{ Users } & \multicolumn{2}{c}{ Nonusers } & X2 & $\mathrm{p}$ \\
\cline { 2 - 5 } & Education & Science & Education & Science & \\
\hline Cabri & 33 & 4 & 128 & 18 & $1.00^{\mathrm{a}}$ \\
Sketchpad & 12 & 2 & 149 & 20 & $.678^{\mathrm{a}}$ \\
Scetch up & 2 & 2 & 159 & 20 & $.071^{\mathrm{a}}$ \\
GeoGebra & 113 & 15 & 48 & 7 & .000 & $1.00^{\mathrm{b}}$ \\
Logo & 4 & 3 & 157 & 19 & $.039^{\mathrm{a}}$ \\
\hline
\end{tabular}

a Fisher's exact test (effectives <5); b Pearson's Chi-squared test with Yates's continuity correction

As can be seen in Table 3, the ratio of teachers using Logo software was found to be statistically significant in favors of science faculty graduates $(\mathrm{p}<.05)$. There was no statistically significant effect of the graduated faculty in relation to other DGS systems ( $p>$.05). The result of the chi-squared test to determine whether usage of teachers' DGS systems is dependent on their level of education is given in Table 4. 
Table 4. Distribution of DGS usage status by level of education.

\begin{tabular}{|c|c|c|c|c|c|c|}
\hline & \multicolumn{2}{|c|}{ Users } & \multicolumn{2}{|c|}{ Nonusers } & \multirow{2}{*}{$\mathbf{X}^{2}$} & \multirow[b]{2}{*}{$\mathrm{p}$} \\
\hline & Graduate & Postgraduate & Graduate & Postgraduate & & \\
\hline Cabri & 30 & 7 & 136 & 10 & 3.77 & $.024^{b}$ \\
\hline Sketchpad & 10 & 4 & 156 & 13 & & $.029 \mathrm{a}$ \\
\hline Scetch up & 2 & 2 & 164 & 15 & & $.044^{\mathrm{a}}$ \\
\hline GeoGebra & 116 & 12 & 50 & 5 & .00 & $1.00^{b}$ \\
\hline Logo & 5 & 2 & 161 & 15 & & $.13^{\mathrm{a}}$ \\
\hline
\end{tabular}

a Fisher's exact test (effectives $<5$ ); b Pearson's Chi-squared test with Yates's continuity correction

According to Table 4, distribution of usage of Cabri, Sketcpad and Sketchup dynamic geometry software is statistically significant in favors of post-graduate teachers $(\mathrm{p}<.05)$. There is no statistically significant effect of learning level on the usage in relation to other DGS systems ( $p>.05)$. The results of the chi-squared test to determine whether teachers' use of DGS is dependent on the level of technology use are given in Table 5.

Table 5. Distribution of DGS usage status by technology usage level.

\begin{tabular}{lcccccc}
\hline & \multicolumn{2}{c}{ Users } & \multicolumn{2}{c}{ Nonusers } & \multirow{2}{*}{$\chi^{2}$} & $\mathrm{p}$ \\
\cline { 2 - 6 } & Medium & High & Medium & High & & \\
\hline Cabri & 12 & 25 & 100 & 46 & 14.68 & $.000^{\mathrm{b}}$ \\
Sketchpad & 5 & 9 & 107 & 62 & 3.07 & $.080^{\mathrm{b}}$ \\
Sketch up & 1 & 3 & 111 & 68 & & $.300^{\mathrm{a}}$ \\
GeoGebra & 73 & 55 & 39 & 16 & 2.56 & $.109^{\mathrm{b}}$ \\
Logo & 3 & 4 & 109 & 67 & & $.433^{\mathrm{a}}$ \\
\hline
\end{tabular}

a Fisher's exact test (effectives <5); bearson's Chi-squared test with Yates's continuity correction

As can be seen in Table 5, it was found that the use of Cabri was statistically significant in favour of teachers with a high perception level for technology use $(\mathrm{p}<.05)$. There was no statistically significant effect of the level of perception on the level of technology usage in relation to other DGS systems ( $>$ >.05). Table 6 shows the result of the 
chi-squared test to determine whether teachers' use of DGS is dependent on their professional experience.

Table 6. Distribution of DGS usage status by occupational experience year

\begin{tabular}{|c|c|c|c|c|c|c|}
\hline & \multicolumn{2}{|l|}{ Users } & \multicolumn{2}{|l|}{ Nonusers } & \multirow{2}{*}{$X^{2}$} & \multirow{2}{*}{$\mathrm{p}$} \\
\hline & Years $<=10$ & Years $>10$ & Years $<=10$ & Years $>10$ & & \\
\hline Cabri 3D & 34 & 3 & 108 & 38 & 4.47 & $.037^{\mathrm{b}}$ \\
\hline Sketchpad & 12 & 2 & 130 & 39 & & $.739 \mathrm{a}$ \\
\hline Scetch up & 2 & 2 & 140 & 39 & & $.217^{\mathrm{a}}$ \\
\hline GeoGebra & 102 & 26 & 40 & 15 & .71 & $.336^{b}$ \\
\hline Logo & 5 & 2 & 137 & 39 & & $.65^{\mathrm{a}}$ \\
\hline
\end{tabular}

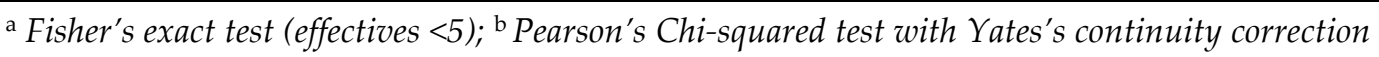

As can be seen in Table 6, the distribution of teachers using Cabri dynamic geometry software is statistically significant in favour of teachers who have less than 10 years professional experience $(\mathrm{p}<.05)$. Also, there is no statistically significant effect of the professional experience year on usage of other DGS systems ( $\mathrm{p}>.05)$.

\section{Discussion and Conclusions}

In this research, the pedagogical potentials and limitations of DGS have been revealed and many proposed solutions have been presented. In addition, the effects of gender, grade, and level of education, skill in using technology and professional experience in the preferences of Cabri (2D/3D/Plus), the GSP, Google SketchUp, GeoGebra and Logo DGS by primary mathematics teachers have been examined. When the literature on DGS is reviewed, it is stated that it provides an effective pedagogical environment because it allows for interaction with digital materials and for geometric objects to be seen from all sides. In addition, interacting with geometric materials through DGS helps students understand geometrical concepts more easily as well as exploring the relationships between geometrical concepts (Jones, 2002). Although use of DGS in geometry teaching is actively promoted within the curriculum, ongoing reforms and new regulations, it is frequently stated in relevant studies that teachers have serious difficulties in adapting this software to the classroom environment. One of the most important reasons why teachers cannot combine technology with classroom pedagogy is that they do not have enough experience. In 
addition, perceived usefulness and perceived ease of use are two important factors that determine the intention of teachers to use DGS software in the classroom (Stols \& Kriek 2011). Therefore, both teachers' pedagogical beliefs and technology competencies should be taken into consideration (Ertmer, 2005).

In this study, the following results were also found on effects of gender, age, level of education, skill in using technology and professional experience in preferences of DGS use by primary mathematics teachers.

GeoGebra seems to be the most used DGS by teachers (70\%). Cabri is used by $30 \%$ of primary school mathematics teachers. Other DGS packages seem to have a very low usage rate (Dogan \& İçel, 2011). It is noted that GeoGebra is free and its interface is Linux-based and easy to use, which could explain why teachers prefer it the most. In addition, $25 \%$ of teachers stated that they have not used the DGS packages mentioned in this research, while $7 \%$ have not used other online and computer-based teaching materials besides DGS. This shows that a significant number of teachers only uses textbooks in geometry lessons (Bruce, Flynn, Ross \& Moss, 2011; Clements \& Sarama, 2011; Kösa, 2011).

It has been found that the use of Logo by graduates from science faculties is higher than that of graduates from education faculties, and that the use of other software does not have an effect in terms of which faculty teachers graduated from. Because the logo software requires programming knowledge, it requires the student to define various commands and follow a logical sequencing algorithm. For this reason, it remains abstract for younger students (Clements \& Sarama, 1997) and is used more frequently in the faculties of science. However, since the 5th grade, there is a strong potential in the faculties of education due to the inclusion of programming topics within the curriculum of information technologies and software courses. So, this result is interpreted as indicating that education faculties need to provide more space for technology and pedagogy issues in the training of primary mathematics teachers, and that training possibilities with many DGS should be increased.

The use of Cabri, the GSP and Google SketchUp by teachers who teach primary school mathematics with a postgraduate qualification is found to be higher than in the case of teachers with an undergraduate degree. This result is due to the fact that postgraduates who teach primary school mathematics have higher qualifications in the fields of technology, pedagogy and teaching. In this sense, postgraduate teachers are able to adapt DGS to the teaching and classroom environment more easily (Kabaca, Aktümen, Aksoy \& Bulut, 2010). 
It is found that the rate of using Cabri is higher for teachers whose professional experience is shorter than others and who have a higher technology usage level. This has been interpreted as the recent graduation of teachers from the faculty of education has a high level of technological competence, experience and awareness of Cabri3D. Therefore, the technology usage level of these teachers effected teachers' intention to use Cabri3D over perceived ease of use and perceived usefulness (Teo \& Milutinovic, 2015, Wong, 2015).

\section{Suggestions and Limitations}

The following recommendations are suggested for the contribute to the development of appropriate policies by key institutions such as Council of Higher Education, universities, Ministry of Education that can contribute to the quality of teacher training.

- It is important for teachers to adopt innovative approaches and not be prejudiced against the use of technology. For this reason, within the scope of the geometry curriculum, the combination of pedagogy and technology should be provided in order to observe and support students' progress in this matter.

- In the pedagogical integration of technology, it is necessary to test individual deductions of students and identify tasks that encourage the use of tools and activities aimed at understanding the concepts of geometry.

- The variety of knowledge teachers need to be defined in a standardized and explicit way to better understand the Technological Pedagogical Content Knowledge model and to better understand the changes that teachers will encounter in the integration of technology in educational integration.

- Teachers' awareness of the fields of pedagogy and technology can also enrich the way they are able to make sense of the relationship between these fields and ensures that they are more successful in delivering education.

- Regular and appropriate targets should be defined and used in order for DGS to make a difference in education. Also a control group should be established where teachers can discuss and solve the problems they face in order to reduce prejudices towards and adaptations some of them make to undermine technology-assisted instruction.

- The diverse knowledge that teachers need to pass onto students should be defined in a standardized and explicit way, in order to better understand the technological 
pedagogical content knowledge model, as well as the changes that teachers will encounter in the integration of technology in education settings.

In order to better understand the intention of mathematics teachers to accept and use DGS systems, it would be beneficial conducting further research examine the effect of different variables by using Technology Acceptance Model. Also, the research conducted in this paper has some limitations. This research data is limited to the survey data obtained from elementary mathematics teachers in Turkey. For this reason, in subsequent studies it is recommended to compare these findings with quantitative and qualitative data obtained from different samples, cultures and countries. The results of this research will contribute to the development of appropriate policies by key institutions such as Council of Higher Education, universities, Ministry of Education that can contribute to the quality of teacher training.

\section{References}

Adulyasas, L., \& Abdul Rahman, S. (2014). Lesson study incorporating phase-based instruction using geometer's sketchpad and its effects on thai students' geometric thinking. International Journal for Lesson and Learning Studies, 3(3), 252-271.

An, J., \& Park, N. (2011). Computer application in elementary education bases on fractal geometry theory using logo programming. In IT convergence and services (pp. 241-249). Springer, Dordrecht.

Arzarello, F., Olivero, F., Paola, D., \& Robutti, O. (2002). A cognitive analysis of dragging practises in Cabri environments. Zentralblatt für Didaktik der Mathematik, 34(3), 66-72.

Baki, A. (2002). Öğrenen ve öğretenler için bilgisayar destekli matematik [Computer aided mathematics for learners and teachers]. İstanbul: Ceren Yayınları.

Baki, A., \& Özpınar, İ. (2007). Logo destekli geometri öğretimi materyalinin öğrencilerin akademik başarılarına etkileri ve öğrencilerin uygulama ile ilgili görüşleri [The effects of logo-assisted geometry teaching material on students' academic achievement and students' views on implementation]. Çukurova University Faculty of Education Journal, 34(3), 153-163.

Balram, S. (2019). Teaching and learning pedagogies in higher education geographic information science. In GIScience Teaching and Learning Perspectives (in Press). Springer, Cham.

Bray, A., \& Tangney, B. (2017). Technology usage in mathematics education research-A systematic review of recent trends. Computers $\mathcal{E}$ Education, 114, 255-273. 
Bruce, C., Flynn, T., Ross, J., \& Moss, J. (2011). Promoting teacher and student mathematics learning through lesson study: a design research approach. In B. Ubuz (Ed.), Proceedings of the thirtyfifth conference of the International Group for the Psychology of Mathematics Education (Vol. 2, pp. 193-200). Ankara: PME.

Clements, D. H., \& Sarama, J. (2011). Early childhood teacher education: the case of geometry. Journal of Mathematics Teacher Education, 14(2), 133-148.

Çelik, A., Erduran, A., \& Eryiğit, P. (2016). The effect of utilizing the three dimensional dynamic geometry software in geometry teaching on $12^{\text {th }}$ grade students, their academic success, and their attitudes towards geometry. Buca Faculty of Education Journal (41), 1-16.

Çetin, Y. \& Mirasyedioğlu, Ş. (2019). Teknoloji destekli probleme dayalı öğretim uygulamalarının matematik başarısına etkisi [The Effects of the Technology Supported Problem-Based Learning Activities on Students' Achievement in Mathematics]. Journal of Computer and Education Research, 7 (13), 13-34. DOI: 10.18009/jcer.494907

Çiftçi, O., \& Tatar, E. (2014). The comparison of the effectiveness of the using compassstraightedge and a dynamic software on achievement. Journal of Computer and Educational Research, 2(4), 111-133.

Chou, P. N., Chen, W. F., Wu, C. Y., \& Carey, R. P. (2017). Utilizing 3D open source software to facilitate student learning of fundamental engineering knowledge: a quasiexperimental study. International Journal of Engineering Education, 33(1), 382-388.

Dixon, J. K., (1997). Computer use and visualization in students' construction of reflection and rotation concepts, School Science \& Mathematics, 97(7), 352-358.

Dogan, M., \& İçel, R. (2011). The role of dynamic geometry software in the process of learning: GeoGebra example about triangles. Journal of Human Sciences, 8(1), 1441-1458.

Erkoç, M. F., Gecü, Z., \& Erkoç, Ç. (2013). The effects of using google sketchup on the mental rotation skills of eighth grade students. Educational Sciences: Theory E Practice, 13(2), 1285.

Ertmer, P. A. (2005). Teacher pedagogical beliefs: The final frontier in our quest for technology integration? Educational Technology Research E Development, 53(4), 25-39.

Eryiğit, P. (2010). The effect of utilizing the three dimensional dynamic geometry software in geometry teaching on 12th grade students, their academic standings, their attitude towards geometry. Doctoral dissertation, Dokuz Eylül University, Institute of Educational Sciences, Elementary Mathematics Education.

Filiz, M. (2009). The effect of using geogebra and cabri geometry II dynamic geometry softwares in a web-based setting on students' achievement. Unpublished Master's Thesis, Karadeniz Technical University, Trabzon.

Gooler, D., Kantzer, K., \& Knuth, R. (2000, November). Teacher competence in using technologies: The next big question. Honolulu, HI: Pacific Resources for Education and Learning. 
Gökkurt, B., Deniz, D., Soylu, Y., \& Akgün, L. (2012). Students' views about work sheets prepared with the dynamic geometry software: area example on prisims. Journal of Research in Education and Teaching, 1(3), 358-363.

Gökkurt, B., Dündar, S., Soylu, Y. \& Tatar, E. (2012). Developing suitable materials for the computer enriched learning cycle model: teaching the "Pyramid" subject. 4th World Conference on Educational Sciences (WCES-2012), 46, 3129-3133

Günhan, B. C., \& Açan, H. (2016). The effect of using dynamic geometry software on the success of geometry: a meta-analysis study. Turkish Journal of Computer and Mathematics Education, 7(1), 1-23.

Güven, B. \& Karataş İ. (2003). Dinamik geometri yazılımı Cabri ile geometri öğrenme: öğrenci görüşleri [Learning Geometry with Dynamic Geometry Software Cabri:Student Opinions]. The Turkish Online Journal of Educational Technology, 2(2), 67-78.

Hinkle, D. E., Wiersma, W., \& Jurs, S. G. (2003). Applied statistics for the behavioral sciences (Vol. 663). Houghton Mifflin College Division.

Hohenwarter, J., Hohenwarter, M., \& Lavicza, Z. (2009). Introducing dynamic mathematics software to secondary school teachers: The case of GeoGebra. Journal of Computers in Mathematics and Science Teaching, 28(2), 135-146.

Holloway, J. H. (1999). Caution: constructivism ahead. Educational Leadership, 57 (3), 85-86.

İçel, R. (2011). Effects of computer based teaching on students' mathematics achievements: Example of GeoGebra, Doctoral dissertation, Selçuk University, Institute of Educational Sciences, Elementary Mathematics Education.

Jones, K. (2002). Research on the use of dynamic geometry software: implications for the classroom. MicroMath, 18(3), 18-20.

Kabaca, T., Aktümen, M., Aksoy, Y. \& Bulut, M. (2010). Introducing the in-service mathematics teachers with the dynamic mathematics software geogebra and their views about geogebra. Turkish Journal of Computer and Mathematics Education, 1(2),148165.

Khine, M. S. (2017). Spatial Cognition: Key to STEM Success. In Visual-spatial Ability in STEM Education (pp. 3-8). Springer, Cham.

Koehler, M.J., Mishra, P., \& Yahya, K. (2007). Tracing the development of teacher knowledge in a design deminar: Integrating content, pedagogy and technology. Computers $\mathcal{E}$ Education, 49, 740-762.

Kösa, T. (2011). An investigation of secondary school students' spatial skills. Unpublished Master's Thesis, Karadeniz Technical University, Institute of Educational Sciences, Elementary Mathematics Education, Trabzon.

Köse, N. (2008). Determining fifth grade primary school students? understanding of symmetry using dynamic geometry software cabri geometry: An action research. Doctoral dissertation, Anadolu University, Institute of Educational Sciences, Eskişehir.

Kurtuluş, A., \& Uygan, C. (2016). Using Google SketchUp software for teaching geometry. Mehmet Akif Ersoy University, Faculty of Education Journal, 1(40), 191-207. 
Kutluca, T. (2013). The effect of geometry instruction with dynamic geometry software; GeoGebra on van hiele geometry understanding levels of students. Educational Research and Reviews, 8(17), 1509-1518.

Leung, A. (2011). An epistemic model of task design in dynamic geometry environment. ZDM, 43(3), 325-336.

Mishra, P., \& Koehler, M. (2009). Too cool for school? no way! using the TPACK framework: you can have your hot tools and teach with them, too. Learning $\mathcal{E}$ Leading with Technology, 36(7), 14-18.

Mishra, P., \& Koehler, M. J. (2006). Technological pedagogical content knowledge: A framework for teacher knowledge. Teachers college record, 108(6), 1017.

Ozuah, P. O. (2016). First, there was pedagogy and then came andragogy. Einstein journal of Biology and Medicine, 21(2), 83-87.

Pereira, L. R., Jardim, D. F., \& da Silva, J. M. (2017, December). Modelling plane geometry: The connection between Geometrical Visualization and Algebraic Demonstration. In Journal of Physics: Conference Series, Vol. 936, No. 1, p. 012068). IOP Publishing.

Pavlovičová, G., \& Švecová, V. (2015). The development of spatial skills through discovering in the geometrical education at primary school.Procedia-Social and Behavioral Sciences, 186, 990-997.

Priatna, N. (2017, September). Students' spatial sbility through open-ended approach aided by Cabri 3D. In Journal of Physics: Conference Series (Vol. 895, No. 1, p. 012065). IOP Publishing.

Romero, I. M., del Mar García, M., \& Codina, A. (2015). Developing mathematical competencies in secondary students by introducing dynamic geometry systems in the Classroom, Education and Science, 40, 43-58.

Saeli, M. J., Perrent, W., \& Jochens Zwaneveld, B. (2011). Teaching programming in secondary school: A pedagogical content knowledge perspective. Informatics in Education, 10(1), 73-88.

Simmons, M., \& Cope, P. (1997). Working with a round turtle: the development of angle/rotation concepts under restricted feedback conditions. Computers $\mathcal{E}$ Education, 28(1), 23-33.

Sinclair, N., \& Crespo, S. (2006). Learning mathematics in dynamic computer environments. Teaching Children Mathematics, 437-444.

Şimşek, E., \& Yücekaya, G. K. (2014). The effect of the teaching by the dynamic geometry software on 6th grade elemantary school students' spatial ability. Ahi Evran University Journal of Kirsehir Education Faculty, 15(1).

Stols, G., \& Kriek, J. (2011). Why don't all maths teachers use dynamic geometry software in their classrooms?. Australasian Journal of Educational Technology, 27(1).

Taş, U. E., Arıcı, Ö., Ozarkan, H. B., \& Özgürlük, B. (2016). PISA 2015 ulusal raporu [PISA 2015 national report]. Ankara: Ministry of Education. 
Teo, T., \& Milutinovic, V. (2015). Modelling the intention to use technology for teaching mathematics among pre-service teachers in Serbia. Australasian Journal of Educational Technology, 31(4).

Tieng, P. G., \& Eu, L. K. (2014). Improving students' van hiele level of geometric thinking using geometer's sketchpad. Malaysian Online Journal of Educational Technology, 2(3), 2031.

Uğur, B., Urhan, S., \& Kocadere, S. A. (2016). Teaching geometric objects with dynamic geometry software. Necatibey Faculty of Education Electronic Journal of Science and Mathematics Education, 10 (2), 339-366.

Valentine, K. D. (2018). Tinkering with Logo in an elementary mathematics methods course. Interdisciplinary Journal of Problem-Based Learning, 12(2), http://doi.org/10.7771/1541-5015.1754

Wiest, L. R. (2001). The role of computers in mathematics teaching and learning, Computers in the Schools, 17(1-2), 41-55.

Wong, G. K. (2015). Understanding technology acceptance in pre-service teachers of primary mathematics in Hong Kong. Australasian Journal of Educational Technology, 31(6). 